\title{
Judicialização da política e democracia
}

\section{Fabiano Engelmann*}

A noção de "judicialização da política" aparece desde a década de 60 na ciência política americana como resultante da análise do fenômeno de crescimento da importânci do poder Judiciário no sistema político, en especial da Suprema Corte. O Judiciári desponta como um poder contramajoritário capaz de desconstituir decisões de governo e influenciar no direcionamento de políticas públicas. Na base desses processos estão mecanismos institucionais, como o controle de constitucionalidade que confere às cortes prerrogativa de dizer a última palavra sobre a "adequação às regras" de decisões governamentais, de atos legislativos e mesmo do próprio jogo político-eleitoral.

Em outro sentido, também édesenvolvid - a partir do estudo do caso americano noção de "ativismo político-judicial", que tenta explicar as lógicas da expansão das causa judiciais pelo envolvimento das demandas de minorias sociais. Nessa perspectiva, para além dos mecanismos institucionais que induzem à “judicialização da política”, temo como centro da análise as estratégias de mobilização do espaço judicial por movimentos sociais, assim como a emergência de uma advocacia especializada em representar causa políticas junto aos tribunais. Determinados movimentos, inclusive, utilizaram com estratégia principal de luta política o litígio judicial, visando reconhecer direitos ou demandar políticas de governo, fortalecendo profissionalização de advogados militantes encarregados de "pôr na forma jurídica" demandas políticas. Apesar da origem mai nítida no caso americano, tanto o fenômen da "judicialização da política" quanto as praticas do "ativismo judicial" são observados também em outras democracias e mesmo em países com regimes autoritários. No último caso, apesar das limitações do contexto jurídico-político, o Judiciário torna-se uma tribuna de resistência e denúncia de violações de direitos civis.

As interpretações da ciência política para essa crescente interação entre o espaço judicial e o espaço político divide-se entre uma visão mais "pessimista" e uma mais "otimista" em relação a seus custos e benefícios para o regime democrático. A primeira percepção destacou os limites do protagonismo judicial em influenciar políticas públicas. Alguns autores chegaram a tratar esse ativismo como um desvirtuamento de funções do Judiciário, que deveria ficar restrito ao controle da legalidade do jogo político e dos atos dos governos. A visão "otimista” destacou o caráter contramajoritário do poder e sua capacidade de tutelar as demandas das minorias sociais e políticas, agindo, nesse sentido, como um sociais e como um espaço legítimo para mediar demandas coletivas que não encontram respaldo no Legislativo e no Executivo.

No caso brasileiro, parte significativa do crescimento do protagonismo político das instituições judiciais foi desencadead a partir da vigência da que forneceu a base institucional para o retorno dos juristas ao espaço do poder político. A alavancagem da "judicialização da política”, entretanto, não se explica somente prerrogativas do poder Judiciário frente aos poderes Legislativo e Executivo. É preciso adicionar ainda outras variáveis, como as mudanças geracionais no recrutamento de juízes e promotores que ocorrem entre a década de 90 e 2000, projetando para es- sas instituições quadros jovens e ciosos de fazer-valer suas prerrogativas e sua posição de poder adquirida através de um concurso público. Também é preciso considerar os efeitos de diferentes conjunturas políticas na interação dessas instituições e agentes com o espaço político.

Nesse mesmo período, o Judiciário comecou a se destacar como mediador de políticas públicas. A "judicialização da saúde” tornouse recorren buscam a distribuição de medicamentos ou internações hospitalares negadas na esfera da administração municipal e estadual. Também outras demandas "sociais" desaguaram no Judiciário, tais como as relacionadas à educação (vagas em escolas públicas) e a problemas ambientais. Da mesma forma, nesse período, não podemos esquecer a consolidação do Ministério Público como fiscal de atos da administração pública em diversas esferas de governo, além de instituição dotada de prerrogativa para representar o "interesse público" judicialmente. Além disso, temos a explosão nos âmbitos federal e estadual das ADINs (Ações Diretas de Inconstitucionalidade). Esse instrumento é utilizado especialmente por minorias políticas no Legishativo para questionar judicialmente atos do Judiciário no papel de mediador do jogo político.

As controvérsias sobre o resultado da versão brasileira da "judicialização da política" e do "ativismo judicial", de certa forma reproduzem o debate internacional. Parte da literatura atribuiu o crescimento do protagonismo a um efeito de consolidação da democracia brasileira e do cidadão enquanto "sujeito de direitos". Entretanto, uma visão mais "pessimista" alertou para o sentido contrário. Ou seja, a possibilidade de as instituições judiciais reproduzirem as lógicas de tradições de autoritarismo bloqueadoras da participação e da representação política presentes de forma recorrente na história política do país.

As duas leituras do fenômeno não são necessariamente excludentes. Por outro lado, o cruzamento da trajetória da crescente legitimação do poder Judiciário com o caminho de enfraquecimento da legitimidade do Legislativo e mesmo, mais recentemente, do poder Executivo, merece atenção. Ou seja, os sucessivos escândalos envolvendo membros do poder Legislativo e do Executivo em diferentes esferas, a percepcão de ineficiência das administrações públicas e a fraca identidade entre o sistema partidário e o eleitor, por exemplo, não foram mitigadas com o fortalecimento das instituições judiciais no espaço político. É possível afirmar que essa (des)legitimacão do sistema político lato sensu foi alimentada por versões desse ativismo político-judicial. Nesse sentido, pode-se indagar se o abuso das prerrogativas de controle possuídas pelas instituições judiciais e seus agentes, em relação aos outros poderes, com o predomínio do denuncismo em uma aliança ambivalente entre arena julevar a um efeito bumerangue. Ou seja, em que medida os próprios avanços em termos de independência e autonomia do Judiciário obtidos com a democracia podem ser postos ultado do alargamento da "judicialização da política”.

*Professor do Programa de Pós-graduação m Ciência Politica e Coordenador do Núcleo

de Estudos em Justica e Poder Político (IFCH e CEGOV)

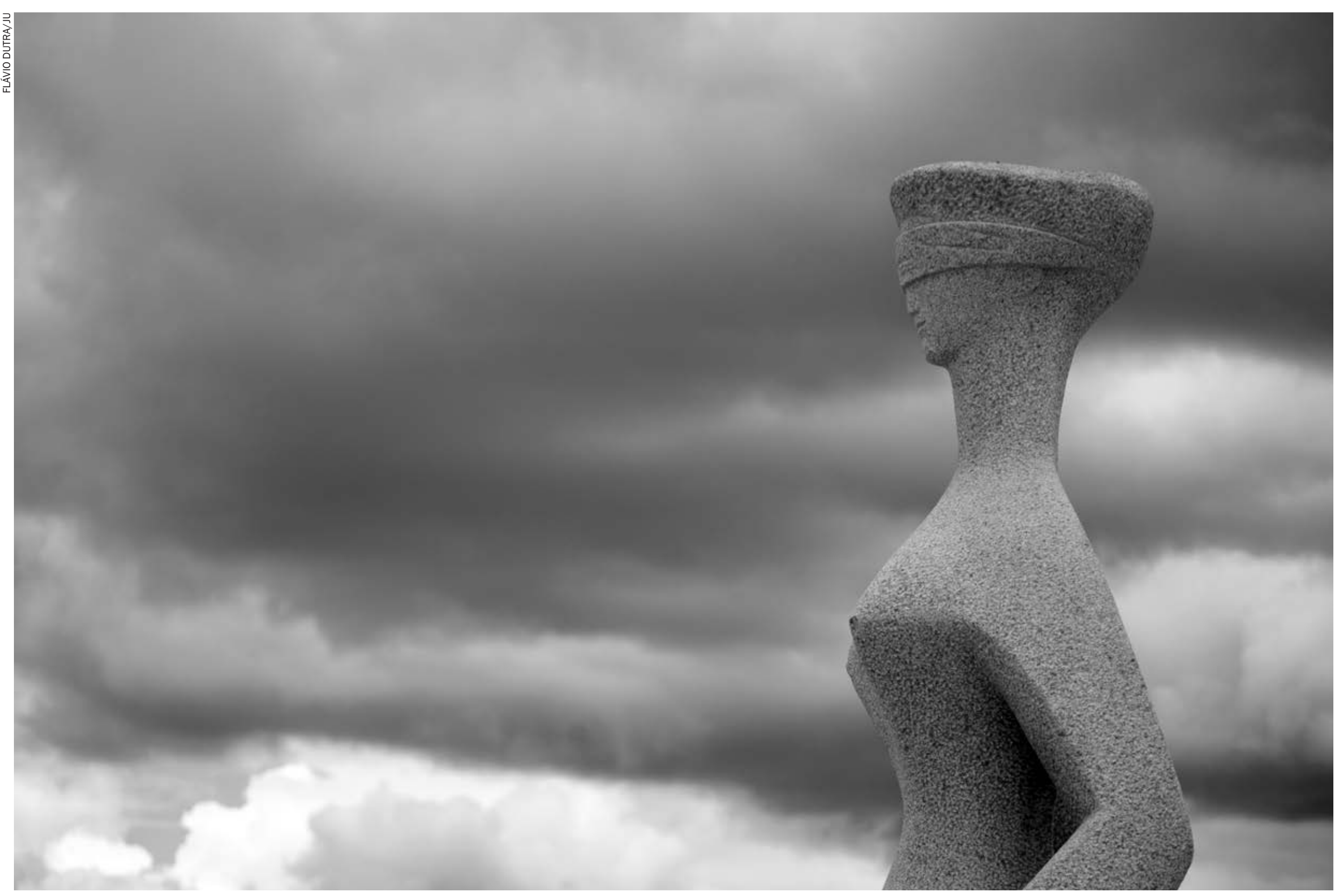

